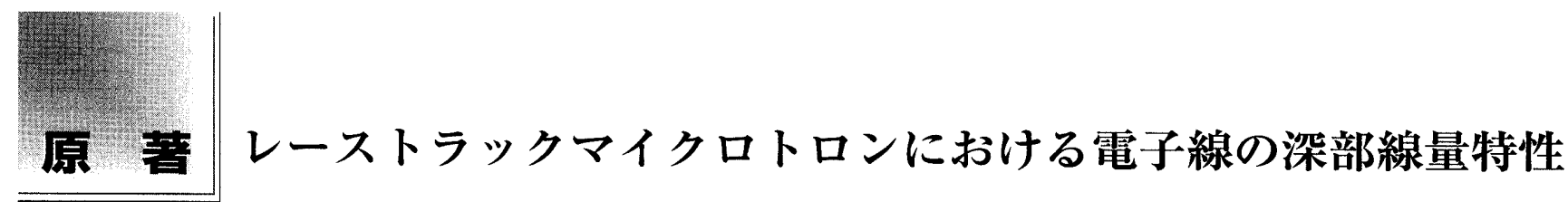

\author{
佐藤智春
}

2001 年 2 月14日論文受付

2001 年 9 論文受理

国立がんセンター中央病院放射線治療部

(現 国立病院東京医療センター放射線科)

Code No. 853

\section{緒 带}

スウェーデンのScanditronix社マイクロトロン MM50(以下, MM50)は, 1984年12月, 世界で初めて 同国のウメオ大学に設置された。 その後，米国に2 台，スウェーデンにもう 1 台，オランダに 1 台設置 され，1999年 3 月，世界で 6 台目が当センターに設 置された，MM50は，現在医療用の電子を加速する装 置としては，最大エネルギーである50MeVの電子線 および50MVのX線を取り出すことができる，レース トラック形のマイクロトロンである．当センターの MM50は 2 ガントリ方式で，10，12，15，20，25， $30,40,50 \mathrm{MeV}$ の計 8 種類の電子線及び 10,20 ,
25，50MVの計 4 種類のX線を使用することができ る. Fig. 1にマイクロトロン本体，ビームトランスポ 一トシステム，スキャンビームシステム，照射ヘッド からなるMM50のシステム構成を示す。これらすべて がコンピュータ制御されており，多種多様なインター ロック機構により，高い安全性を保つことができる。 また治療パラメータにおいても，エネルギーの選択， 投与線量, ガントリ角度, コリメータ角度のみなら ず，寝台位置の認識および移動についてもコンピュー 夕によって制御されており，高度な照射方法を可能に している.

\title{
Depth Dose Characteristics of Electron Beams Released from a Scanning Type Racetrack Microtron Treatment Machine
}

\section{TOMOHARU SATO}

Radiation Oncology Division, The National Cancer Center Hospital (Present address: Department of Radiology, National Tokyo Medical Center)

Received Feb. 14 2001; Revision accepted Sept. 28, 2001; Code No. 853

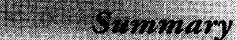

The Racetrack Microtron MM50 capable of taking out x-rays and electron beams having a high energy of up to $50 \mathrm{MeV}$ was evaluated by a dosimetry of electron beams in comparison with Microtron MM22. The MM50 flattens the intensity of electron beams by using the beam scanning method while the MM22 utilizes the flattening-filter method. A percentage depth dose(PDD) curve was obtained through the dosimetry of electron beams using a water phantom. As compared with the MM22, the MM50 emits an electron beam that has an energy much closer to the nominal one, that is less contaminated by $x$-rays, and whose intensity decreases steeply down to near zero on the PDD curve. The MM50 has an electron beam dose distribution that is practically useful since the dose tends to be concentrated on the target volume.

1.7 words: Radiotherapy, Dosimetry, Electron beam characteristics, Racetrack microtron, Beam scanning

別刷資料請求先：テ105-0021 東京都目黑区東が丘2-5-1

国立病院東京医療センター 放射線科 佐藤智春 宛

2002 年 1 月 


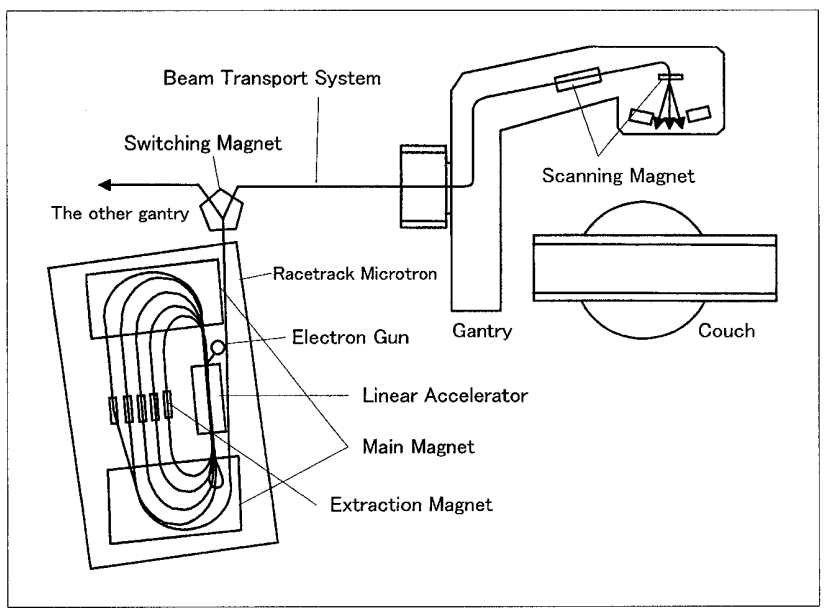

Fig. 1 A schematic view of the MM50 system.

The electron beam is deflected by a main deflection magnet and accelerated after re-incidence into a linear accelerator. At the same time, the electron beam is extracted by using a beam extracting electromagnet. The electron beam is then transported by a beam transport system comprising a switching magnet, a quadrupole electromagnet, and a bending magnet.

\section{MM50の基本構成}

\section{1-1 マイクロトロン本体}

MM50は，電子銃から供給された電子が，マイクロ

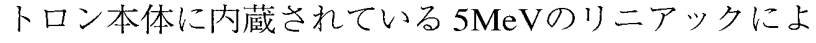
って加速され，雨側に置かれた偏向電磁石 (main magnet)によってレーストラック状の軌道をとり，再 びリニアックに入射して電子が加速される再循環加速 構造となっている.そのエネルギーは $5 \mathrm{MeV}$ の倍数で 増え，最大 $50 \mathrm{MeV}$ ま゙加速される。そして，取り出 したいエネルギーの軌道上にあるビーム取り出し用電 磁石 (extraction magnet)の磁場を強くすることで, そ れまでmain magnet以外の場所では直進していた電子 の軌道が偏向して，ビームを取り出すことができる (Fig. 1).

\section{1-2 ビームトランスポートシステム}

マイクロトロン本体から取り出された電子は，スイ ッチングマグネット (switching magnet)によりどちら か片方の治療室にビームが振り分けられ, 電子の拡散 を抑え収束させるための四極子電磁不，ビームの進行 方向を曲げるためのベンディングマグネット (bending magnet）を含むbeam transport systemにより治療用ガ ントリへ輸送される (Fig. 1).

\section{1-3 スキャンビーム方式}

MM50はビームの平坦化に，フラットニングフィル タではなく，スキャンビーム方式を採用している。こ のスキャンビーム方式は，2台の走査用電磁石

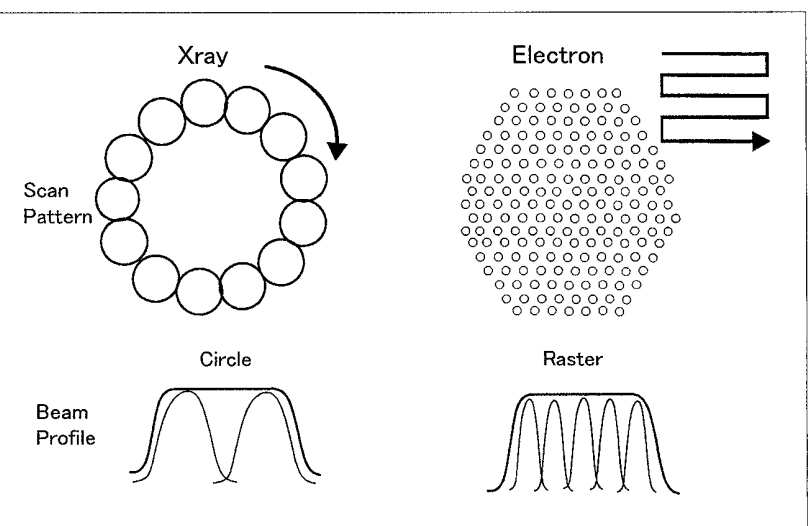

Fig. 2 An explanatory diagram of scan patterns for $x$-rays and electron beams.

The scan pattern of $x$-rays is a circular orbit, while the beam intensity is flattened by raster scanning for electron beams.

(scanning magnet)によりビームの偏向を行い，照射へ ッドから射出したペンシル状のビームをフィールド内 である決まったスキャンパターンで走査し，1 スキャ ン $(1$ サイクル $)$ 終了時にトータルで平坦な照射野が得 られる仕組みになっている. Fig. 2にX線㧤よび電子線 のスキャンパターンを示す、X線はサークル状に走査 し，半值幅10 30cm程度の比較的大きなビームスポ ットで，1サイクル当たり50〜65ビームパルス（ポイン ト)で走查する。また，1サイクル（1 スキャン）に要す る時間は $0.2 〜 0.4$ 秒である。一方，電子線はテレビの 走査線のようなラス夕状に走查し, 半值幅 $5 \sim 7 \mathrm{~cm}$ 程 度の小さなビームスポットで，1 サイクル当たり 500 ～800ビームパルス(ポイント)で走査する。また，1 サイクル（1スキャン)に要する時間は3〜4秒である. なお，電子線の $12 \mathrm{MeV} は 15 \mathrm{MeV}$ 電子線をグラファ イトで減速して取り出している，そのスキャンパター ンは, サークル状でビームスポットの半值幅 $20 \mathrm{~cm}, 1$ サイクル当たり156ビームパルス(ポイント)と他の電 子線とは傾向が異なり，むしろX線に近いスキャンビ 一ム方式となっている。

\section{1-4 照射へッドの構造}

MM50は，スキャンビーム方式により照射野の平坦 度を保っているため, 理論的には散乱箔掠よび平坦化 フィルタは不要である。これら散乱箔および平坦化フ イルタを使用せずに，照射ヘッドから射出したビーム スポットの半值幅は $10 \mathrm{MeV}$ で $5.8 \mathrm{~cm}^{8}$ であるが，エネ ルギーが高くなるほど半值幅は小さくなり，15 $50 \mathrm{MeV}$ では3.5〜 $1.1 \mathrm{~cm}^{8)}$ となる。そこで，これらを実 用的な幅に拡げるために，非常に薄い散乱䇴(15 $25 \mathrm{MeV}$ は真鍮つォイル $0.025 \mathrm{~mm}, 30 \sim 50 \mathrm{MeV}$ は金つ オイル0.025mm）を使用してビームスポットを半值幅 
$7.0 \sim 4.3 \mathrm{~cm}^{8)}$ に拡散させている。

また，照射へッド内すべてがへリウムガスで充たさ れていて，空気による多重散乱により，スキャンビー ムが横方向に拡がることを抑制している。なお，

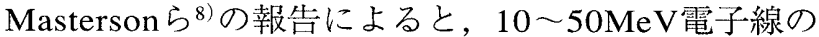
ビームスポットの半值幅は, 空気に対してへリウムガ スでは約60\%小さくなる。

以上述べてきたようにMM50は，リニアックとレー ストラック状の軌道を作るための 2 台のmain magnet を組み合わせた特殊な加速構造により，最大で $50 \mathrm{MeV}$ の電子線を取り出すことが可能である。 また照射野の 平坦化にスキャンビーム方式を取り入れるなど，他の 加速器とは異なる点が多い.とくに，散乱箔および平 坦化フィル夕が不要であること，抢よび照射へッド内 がヘリウムガスで充たされていることなど，特徴ある 照射へッド内の構造により，良好な線質特性を有する 電子線が得られる6)とされている。そこでMM50の電 子線について, 深部量百分率 (percentage depth dose, PDD) 曲線等を測定し，そのパラメー夕を求めること で，ビーム中心軸上における深部特性について評価し た。

\section{2. 方 法}

\section{2-1 実験器材}

PDD曲線の測定には三次元走査式水ファントム Scanditronix社RFA300Plus Ver5.2(以下，RFA)，フィ ールド線量計 RKチエンバ (容積 $0.12 \mathrm{~cm}^{3}$ ) および

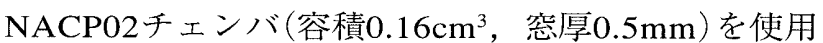
した. 平坦化フィルタ力式の加速器では, 基準検出器 により加速器の出力変動の影響を補正しているが, ス キャンビーム方式であるMM50は, 加速器の出力変動 の補正に，加速器内部のモ二夕線量計の電離電流を利 用している。また，スキャンビーム方式の場合，1 1 ス キャンが完全に終了した時点で平坦な照射野が得られ るため，整数倍のスキャン数で線量測定を行う必要が ある，RFAは，フィールド線量計の位置制御をスキャ ンビームと同期させて行っている。 それゆえに，スキ ヤンビーム方式では測定回数およびポイント数のわり には，非常に測定時間がかかる(Table)。
また，表面線量の評価において，水ファントムでは 表面張力により正確な測定が困難であることから， RMI社Solid Water457およびMix-Dpを使用した。な お，この固体ファントムに使用可能な当センターの線 量計はPTW社23343Markusチェンバ(容積 $0.055 \mathrm{~cm}^{3}$, 膜厚 $0.03 \mathrm{~mm}$ ), 電位差計はNE社FARMERDO SEMETER2570/1であり，これらを使用した。

\section{2-2 測定方法}

RFAにRKチエンバを使用し，電子線のエネルギー $10 ， 12 ， 15 ， 20 ， 30 ， 40 ， 50 \mathrm{MeV}$ ，照射野 $10 \times 10 \mathrm{~cm}^{2}$ にてPDD曲線を測定した。なお，測定は通常の使用状 態で行った。つまり，10，12，15MeVは可変アプリ ケータを装着，20，30，40，50MeVについてはアプ リケータを装着せず，照射へッド内のブロックコリメ ータおよびマルチリーフコリメータ（MLC）により照 射野を形成し測定した。

比較のため当センタ一の円形マイクロトロン, Scanditronix社MM22の電子線3，5，7，9，11，13， $16,18,20,22 \mathrm{MeV}$ について, 可変アプリケータを 装着し照射野 $10 \times 10 \mathrm{~cm}^{2}$ にて，PDD曲線を測定した。 なお，チエンバの選択は，「放射線治療における高エ ネルギーX線および電子線の吸収線量の標準測定法」11) に従い，平均入射エネルギー $10 \mathrm{MeV}$ 以下については NACP02チェンバ，10MeVを超える場合はRKチェン バを使用した。

固体ファントムとMarkusチェンバを使用し，表面 および最大線量深で測定し，PDDで表面線量を評価し た。チェンバの極性効果を考慮して ${ }^{10)}$ ，正負両方の印 加電圧で測定し，その平均值を測定值とした。

\section{2-3 PDDパラメータの算出}

PDDの比較評価をするうえで，いくつかのパラメー タが考えられるが，RFAが有する解析機能を利用し， AAPM TG257)等で示されている以下のパラメータを 用いた. Fig. 3にPDD曲線とそのパラメータの関係を 示す.

Table Measurement conditions of PDD curves for electron beams from MM50 by using RFA300Plus.

\begin{tabular}{lrrrrrrr}
\hline \hline Energy (MeV) & 10 & 12 & 15 & 20 & 30 & 40 & 50 \\
Time per scan (s) & 3.87 & 0.78 & 3.87 & 3.87 & 3.87 & 3.87 & 2.59 \\
Number of sampling per point & 3 & 5 & 3 & 3 & 3 & 3 & 3 \\
Number of point & 65 & 82 & 95 & 60 & 58 & 80 & 94 \\
Time (m) & 16.8 & 6.4 & 24.5 & 15.5 & 15.0 & 20.6 & 16.2 \\
Interval (mm) & 1 & 1 & 1 & 2 & 3 & 3 & 3 \\
\hline
\end{tabular}


(1) $E_{p 0}$ : 表面における最頻エネルギー $(\mathrm{MeV})(\mathrm{ICRU}$

Report354) 加引用)。

$E_{p 0}=0.22+1.98 R_{p}+0.0025 R_{p}$

$R_{p}$ (実用飛程) は線量下降部における変曲点

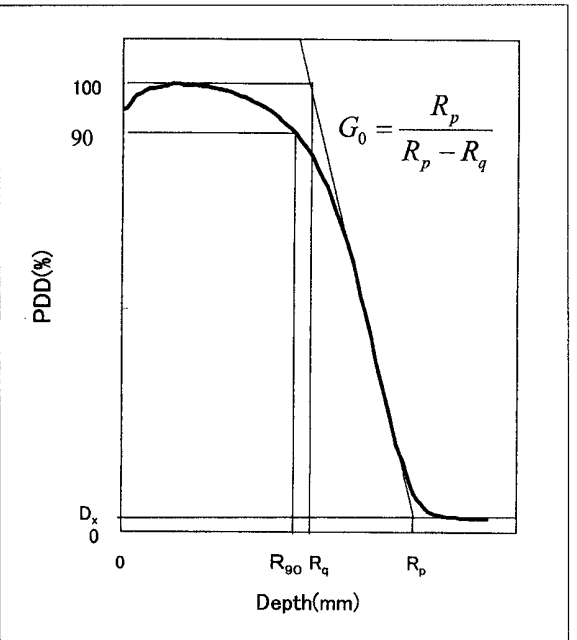

Fig. 3 A percentage depth dose (PDD) curve with each parameters for electron beams.

$D_{\mathrm{x}}$ : Photon background; $\mathrm{R}_{\mathrm{p}}$ : Practical range; $R_{q}$ : Maximum range; $R_{90}$ : Depth at a $90 \%$ level of the maximum dose (therapeutic range); $\mathrm{G}_{0}$ : Gradient at the decreasing part of dose curve.
の接線が， $D_{x}$ を通る横軸に平行な直線と交

差する点の深さ.

(2) $D_{x}$ : フォトンバックグラウンド $(\%)$.

最後の測定点でのPDD值.

(3) $G_{0}:$ 線量下降部の公配.

$G_{o}=R_{p} /\left(R_{p}-R_{q}\right)$

$R_{q}($ 最大飛程) は線量下降部における変曲点の 接線と， $D_{\max }$ を通る横軸に平行な直線との交 点における深さ。なお， $D_{\max }$ は最大線量深で のPDD值 $(100 \%)$

(4) $R_{90}: 90 \%$ 線量レベル深 $(\mathrm{mm})$ (治療飛程).

\section{3. 結 果}

2-2により得たMM50およびMM22の電子線のPDD 曲線をFig.4に示す。

\section{3-1＼cjkstart表面における最頻エネルギー $\left(E_{p 0}\right)$}

Fig. 5に公称エネルギーと $E_{p 0}$ の差を示す。MM50は その差 $0.20 \sim 8.68 \%$ ，平均 $2.11 \%, \mathrm{MM} 22$ は 1.41 $24.62 \%$ ，平均6.10\%であり，MM50はMM22と比較し

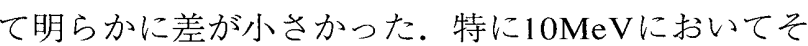
の差は $0.20 \%$ であり， $E_{p 0}$ は公称エネルギーに非常に近 い值を示した。

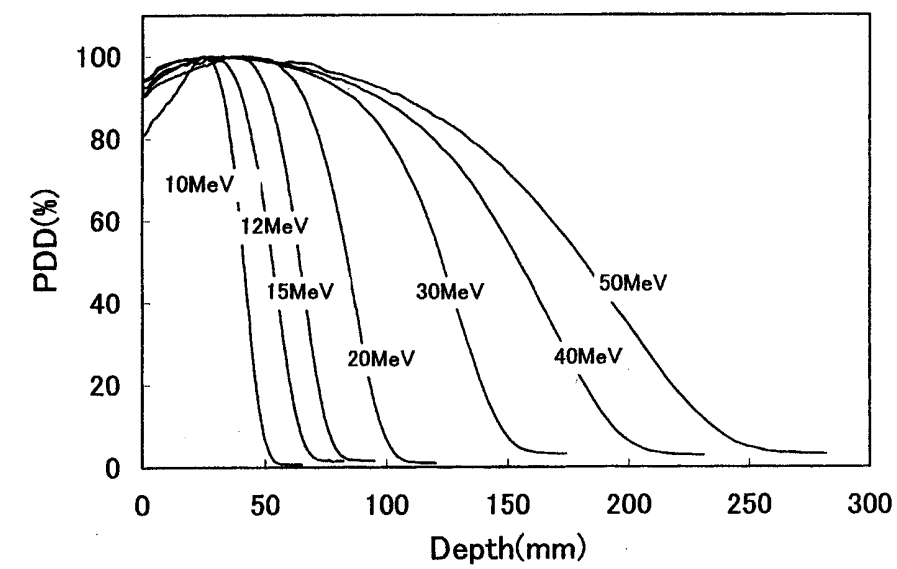

MM50

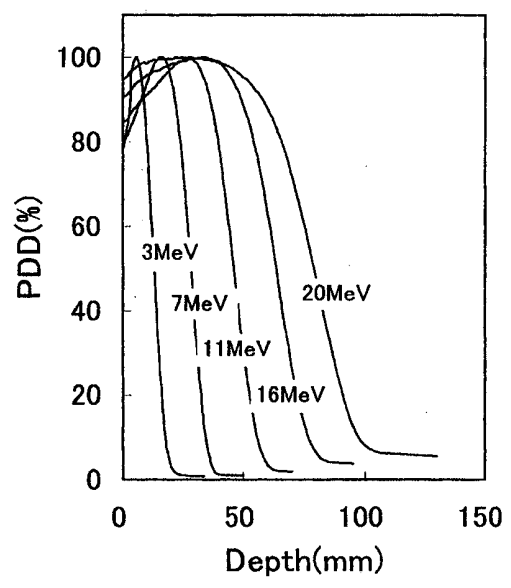

MM22

Fig. 4 PDD curves of electron beams for MM50 and MM22.

The curves were obtained through measurements in normal operating conditions that are, with a variable applicator installed both for MM22 in the entire energy range and for MM50 in the range of 10 to 15 $\mathrm{MeV}$ and with a multileaf collimator (MLC) installed inside the treatment head instead of an applicator for MM50 in the range of 20 to $50 \mathrm{MeV}$. The measurements were made on a water phantom by using the NACP02 chamber for a mean energy at the phantom surface not higher than $10 \mathrm{MeV}$ and by using the RK chamber for a mean energy at the phantom surface higher than $10 \mathrm{MeV}$. 


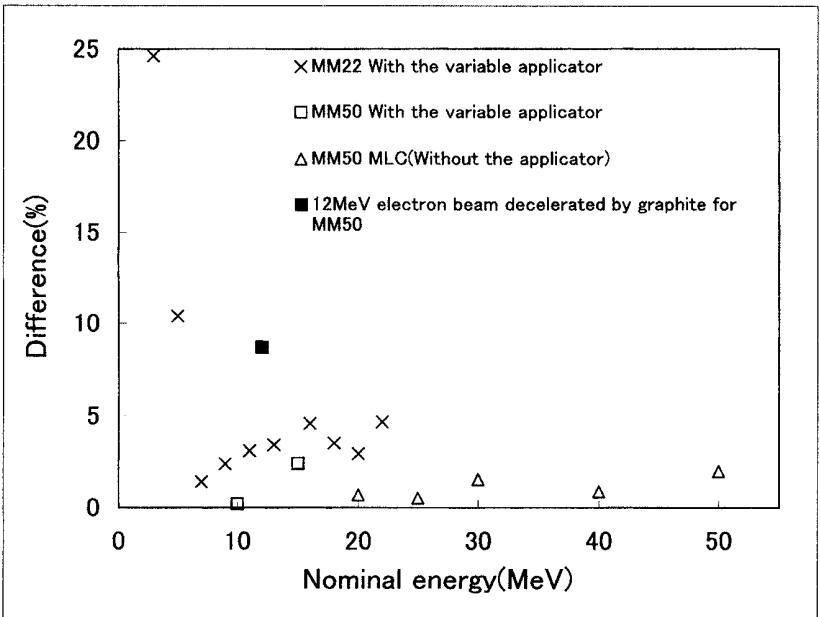

Fig. 5 The difference between the nominal energy and the most probable energy at the phantom surface for electron beams from MM50 and MM22.

The $12 \mathrm{MeV}$ electron beam from MM50 was obtained by decelerating a $15 \mathrm{MeV}$ electron beam by using a graphite. MLC (Multileaf collimator).

\section{3-2 フォトンバックグラウンド $\left(D_{x}\right)$}

Fig. 6にD と電子線エネルギーとの関係を示す. MM50のD は0.7〜3.2\%, MM22は0.9〜5.8\%となり， ともにエネルギーが高くなると $D_{x}$ は大きくなる。ま た，MM50はMM22と比較して有意にD落小さく，制 動放射線による污染が非常に少ない.

\section{3-3 表面線量 $\left(D_{s}\right)$}

Fig. 7に表面線量 $\left(D_{s}\right)$ とエネルギーとの関係を示

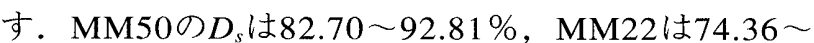
$94.11 \%$ あった。可変アプリケー夕を装着した状 態，つまりMM22すべてのエネルギーとMM50の10 〜 $15 \mathrm{MeV}(82.70 \sim 92.23 \%)$ はエネルギーが高くなるに つれてDは标はなった。一方，アプリケータを装着 せず，照射へッド内のMLCで照射野を形成したMM50 の20～50MeVにおいては92.13９2.81\%であり，大き な変化はなかった。

\section{3-4 90\%線量深 $\left(\mathrm{R}_{90}\right)$}

Fig. 8 に治療飛程である $R_{90}$ を示す， $R_{90}$ について MM50は33.0〜 107.2mm，MM22は10.1〜60.7mmであ り，より高いエネルギーの電子線を出すことができる MM50はMM22と比較して，かなり深部にまで治療領 域が及んでいた。

\section{3-5 線量下降部の勾配 $\left(\mathrm{G}_{0}\right)$}

Fig. 9にPDD曲線における線量下降部の公配 $\left(G_{0}\right)$ を 示す。同じエネルギ一付近にて比較するとMM50 (10MeV 3.05, 15MeV 3.23, 20MeV 3.15), MM22 $(9 \mathrm{MeV}, 2.73,16 \mathrm{MeV}, 3.06,20 \mathrm{MeV}, 2.66)$ とな

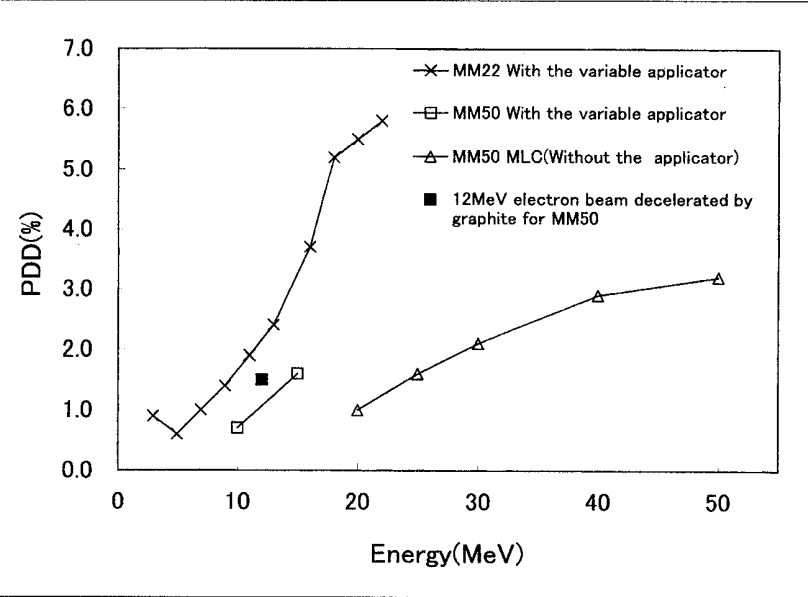

Fig. 6 The comparison of the photon background by the PDD for electron beams from MM50 and MM22. The $12 \mathrm{MeV}$ electron beam from MM50 was obtained by decelerating a $15 \mathrm{MeV}$ electron beam by using a graphite. MLC (Multileaf collimator).

り，明らかにMM50のほうが $G_{0}$ は大きく，線量の低下 が急激であった。

\section{3-6 12MeVの電子線}

MM50の12MeV電子線は，15MeVの電子線をグラ ファイトで減速して取り出している。12MeVについ て公称エネルギーと $E_{p 0}$ との差は $8.68 \% ， D_{x}$ は $1.5 \%$ ， Dsは91.73\%，Gは2.69となった，Fig. 5～9におい て，MM50の同一エネルギー付近 $(10,15 \mathrm{MeV})$ と比較 した場合，公称エネルギーと $E_{p 0}$ との差は大きく， $G_{0}$ は小さくなり, MM50の他エネルギーの電子線とは傾 向が違っていた。

\section{4. 考 察}

4-1 表面における最頻エネルギー $\left(E_{p 0}\right)$

公称エネルギーと $E_{p 0}$ の差について，MM50はMM22 と比較して，明らかに差が小さかった。MM22は加速 構造上，エネルギーの単色性に優れた電子線を取り出 すことができる，マイクロトロン本体で加速された直 後の電子線について，具体的にエネルギースペクトル の半值幅で表すとMM50は300 $\mathrm{keV}^{2)}, \mathrm{MM} 22$ は $35 \mathrm{keV}^{1)}$ であり，この段階ではMM22のほうがエネルギースペ クトルの半值幅は小さい. しかし，その後MM22の電 子線は散乱箔および平坦化フィルタを通過して照射へ ッドから射出する。一方MM50は，スキャンビーム方 式の採用により $10 \mathrm{MeV}$ 電子線はダイレクトに, $15 \mathrm{MeV}$ 以上の電子線は非常に薄い散乱箔のみを通過 して照射へッドから射出する。そのために，エネルギ 一分布の広がる要素が少ないことが，MM50の電子線 について公称エネルギーと $E_{p 0}$ の差がMM22よりも小 


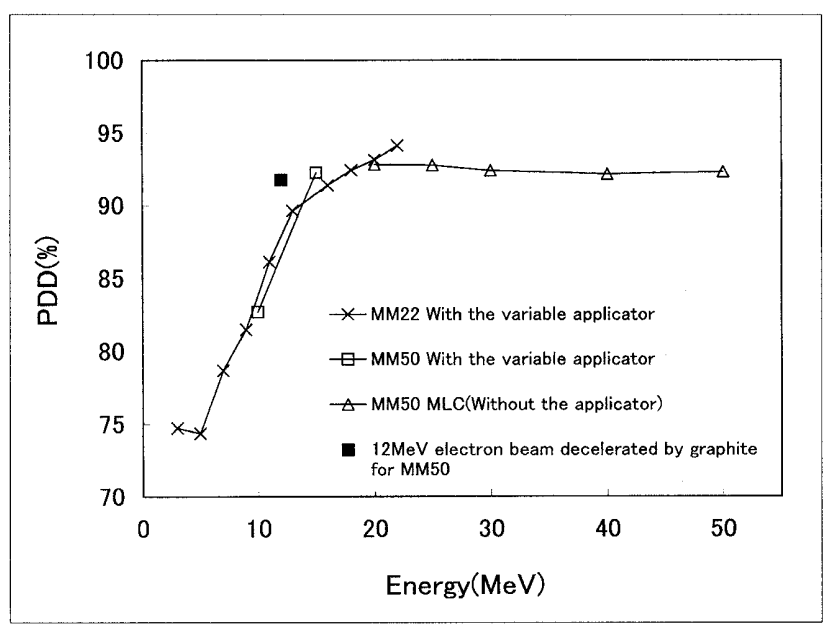

Fig. 7 The comparison of the surface dose by the PDD for electron beams from MM50 and MM22.

The surface dose was measured by using a waterequivalent solid phantom and a Markus chamber. The $12 \mathrm{MeV}$ electron beam from MM50 was obtained by decelerating a $15 \mathrm{MeV}$ electron beam by using a graphite. MLC (Multileaf collimator).

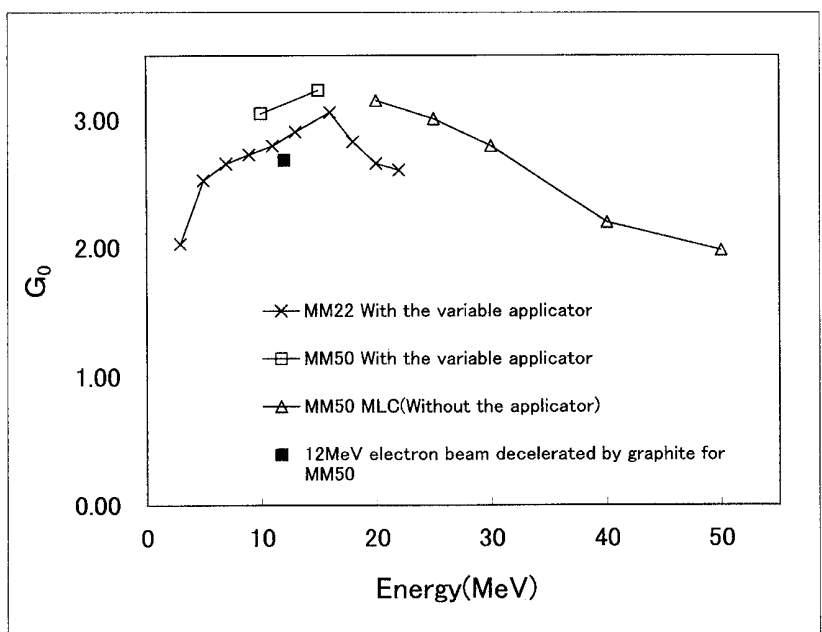

Fig. 9 The comparison of $\mathrm{G}_{0}$ for electron beams from MM50 and MM22.

The $12 \mathrm{MeV}$ electron beam from MM50 was obtained by decelerating a $15 \mathrm{MeV}$ electron beam by using a graphite. MLC (Multileaf collimator).

さい要因と考えられる。これは，散乱箔を通過せずダ イレクトにビームが取り出される $10 \mathrm{MeV}$ 電子線に ついて，公称エネルギーと $E_{p 0}$ の差が $0.20 \%$ と，MM50 の他エネルギーの電子線と比較して, 約10分の 1 しか ないことからも明らかである。

\section{4-2フォトンバックグラウンド $\left(D_{x}\right)$}

電子線は，エネルギーが高くなるほど制動放射によ るX線の割合が増すため， $D_{x}$ は大きくなる，装置別に みると，MM50，MM22ともに，この傾向が表れてい る.

MM22は，散乱箔により電子ビームを拡散し，フラ

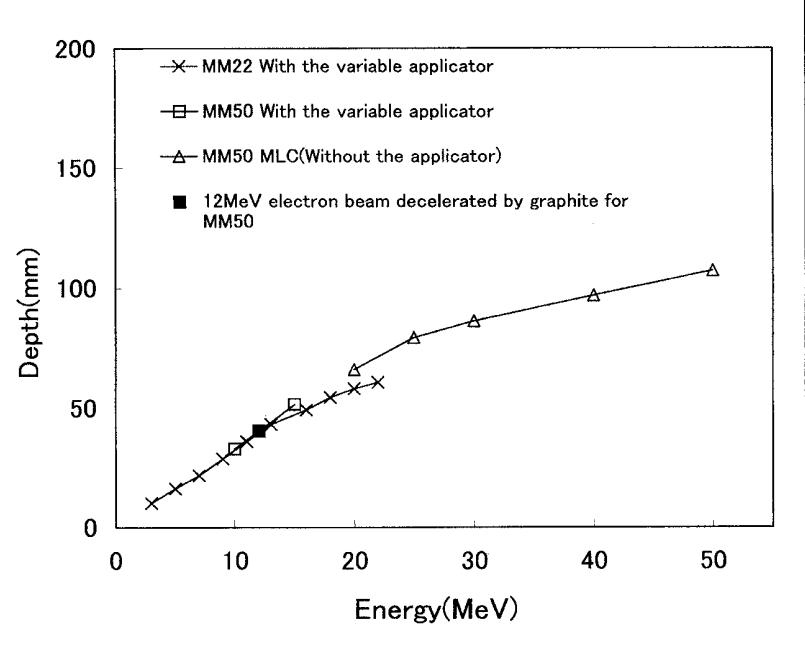

Fig. 8 The comparison of $R_{90}$ for electron beams from MM50 and MM22.

The $12 \mathrm{MeV}$ electron beam from MM50 was obtained by decelerating a $15 \mathrm{MeV}$ electron beam by using a graphite. MLC (Multileaf collimator).

ットニングフィルタにより照射野の平坦化を行う 2 重 フォイルシステムを採用している。しかし，2重フォ イルシステムは $20 \mathrm{MeV}$ 以上の電子線に扔ける高い制 動放射の割合が指摘されている99. 一方，MM50はス キャンビーム方式の採用により，2 重フォイルシステ ムが不要である。今回の実験でもMM22はMM50より も $\mathrm{D}_{\mathrm{X}}$ は大きく，20MeVに扔ける制動放射によるX線 の割合は，MM22が5.5\%であるのに対し，MM50では $1.0 \%$ と非常に小さい值を示した。

\section{4-3 表面線量 $\left(D_{S}\right)$}

$D_{\mathrm{S}}$ について，可変アプリケータを装着した場合，工 ネルギーが高くなるに従い，アプリケータにより散乱 された電子線が増大し， $D_{s}$ の増加に寄与しているもの と思われる。また，MM50は20MeV以上の電子線にお いて，通常，照射ヘッド内のMLCのみで照射野を形 成する. Fig. 7 に示すように，20MeV以上の電子線に おいては，エネルギーが高くなっても $D_{s}$ の変化がほと んどなく，照射へッド内のMLCは，エネルギーの増 加によって表面線量に影響しないことが分かる.

\section{4-4 90\%線量深 $\left(\mathrm{R}_{90}\right)$}

$R_{90}$ はAAPM TG257り扔いて，電子線の深部線量プ ロファイルの臨床における有用な尺度として定義され ている.MM50の30，40，50MeVについて $R_{90}$ は，そ れぞれ，86，97，107mmとなり，哚部にビームを十 分到達させることができるため，これらの電子線によ る体幹部中心に対する照射が可能であると思われる． 


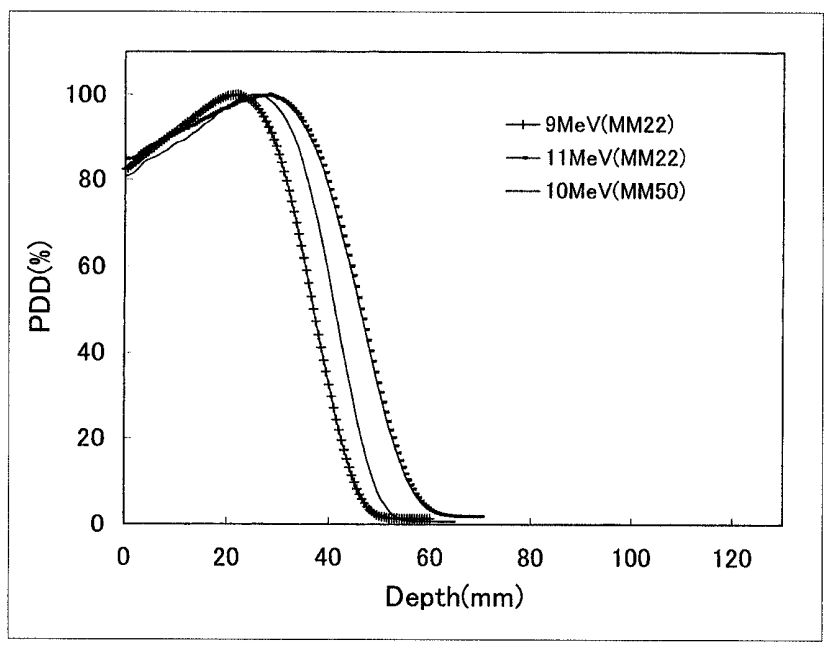

Fig. 10 PDD curves for electron beams from MM50 (10 $\mathrm{MeV}$ ) and MM22 (9 MeV and $11 \mathrm{MeV}$ ).

The measurements were made with variable applicators attached for both MM50 and MM22.

\section{4-5 線量下降部の勾配 $\left(\mathrm{G}_{0}\right)$}

散乱䈃がPDD曲線に与える影響については「放射線 治療における高エネルギーX線掞よび電子線の吸収線 量の標潐測定法」11等に述べられている。散乱䈃の厚 さが増すと, 電子線のエネルギー拡散と角度散乱が増 すので，線量下降部の勾配が緩やかになる。MM50 は，10MeVの電子線では散乱箔がなく，また， $15 \mathrm{MeV}$ 以上の電子線においても非常に薄い散乱䇴を 使用しているため，線量下降部の勾配が急峻である。 したがって，放射線感受性の高い正常器官の近傍での 照射が可能で，標的体積へ集中して線量を投与するこ とができると思われる。

\section{4-6 可変アプリケータ装着時の $10 \mathrm{MeV}$ 付近における MM50およびMM22のPDD曲線}

Fig. 10に可変アプリケータを装着したときの, MM50抢よびMM22の電子線について同一エネルギー 付近のPDD曲線を示す. MM50の $10 \mathrm{MeV}$ とMM22の 9 および11MeVにて，それぞれ， $D_{x}$ は $0.7 \% ， 1.4 \% ， 2.4$ $\% ， G_{0}$ は $3.05,2.73,2.80, R_{90}$ は $33.0 \mathrm{~mm}, 28.2 \mathrm{~mm}$, $36.1 \mathrm{~mm}$ となった。これらの結果から，10MeV付近に お梳るMM50の電子線はMM22と比較して, 明らかに 制動放射線による污染は小さく，線量下降部の低下が 急激である。これらの要因として，MM50の10MeV電 子線は，散乱箔および平坦化フィル夕を通過せずに， ビームはダイレクトに照射ヘッドから射出するため, これらの物質による制動放射およびエネルギーの搪が りによる影響がないことが考えられる。な扮，治療飛 程 $R_{90}$ は， $10 \mathrm{MeV}$ 付近に扔いてMM50とMM22の間

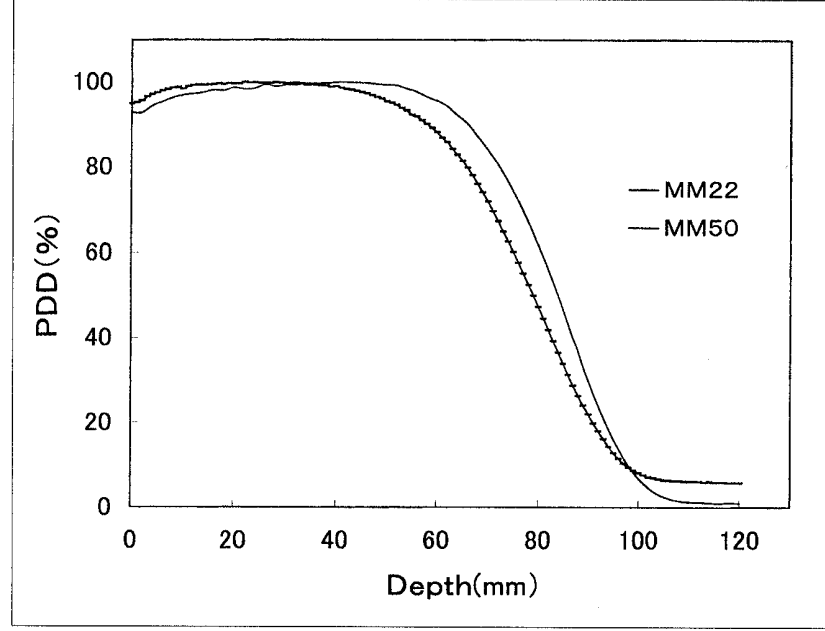

Fig. 11 PDD curves for electron beams from MM50 and MM22 at the same energy of $20 \mathrm{MeV}$.

The measurements were made with a variable applicator installed for MM22 and with a multileaf collimator (MLC) installed inside the treatment head instead of an applicator for MM50.

に，有意な差は認められなかった。また，固体ファン トムにより測定した表面線量 $D_{s}$ は，MM50の $10 \mathrm{MeV}$ と MM22の 9 および11MeVについて，82.70\%，81.48 \%，86.11\%となった。これらの結果は，MM50と MM22の間に有意な差は認められず，両者ともに，可 変アプリケータからの散乱電子等の影響を同様に受け ているためと思われる。

\section{4-7 同一エネルギー(20MeV)におけるMM50および MM22のPDD曲線}

Fig. 11に同一エネルギー $(20 \mathrm{MeV})$ におけるMM50お よびMM22の電子線のPDD曲線を示す。なお， MM50 はMLCで照射野を形成し，MM22は可変アプリケー 夕を装着した，実務的な状態に打いての比較である。 MM50とMM22についてそれぞれ， $D_{x}$ は $1.0 \% ， 5.5$ $\% ， G_{0}$ は $3.15,2.66 ， R_{9_{0}}$ は $66.0 \mathrm{~mm}, 58.1 \mathrm{~mm}$ となっ た。これらの結果から，20MeVに扔けるMM50の電子 線はMM22と比較して, 明らかに制動放射線による污 染は小さく, 線量下降部の低下が急激であり, 治療領 域はより涾部に達していた。これらの要因として, MM50の20MeV電子線は，非常に薄い散乱箔のみを通 過して照射へッドから射出するため，MM22のような 平坦化フィルタおよび散乱箔の厚さによる影響がない ことが考えられる．また，固体ファントムにより測定 した表面線量 $D_{s}$ は， $92.81 \% ， 93.13 \%$ となり，若干 MM22のほうが高い值を示し，アプリケー夕装着によ る散乱電子の影響が，表面線量を多くしている要因で はないかと思われる。 


\section{4-8 12MeV電子線の特性}

MM50の $12 \mathrm{MeV}$ 電子線は15MeVの電子線をグラフ アイトで減速して取り出しており，PDD曲線から得ら れたパラメータの比較において，MM50の他エネルギ 一の電子線とは傾向が違っていた。特にG $G_{0}$ は2.69とな り $10 \mathrm{MeV} ， 3.05 ， 15 \mathrm{MeV} ， 3.23$ と比較しても明らかに PDD曲線の線量下降部の勾配が緩やかであることが分 かる。また，ビームスポットの半值幅について， MM50の他エネルギーの電子線が5〜 7cmであるのに 対し電子線 $12 \mathrm{MeV}$ においては20 cmあり，幅広いビー ムスポットとなっている。これは，グラファイトによ り電子線のエネルギー拡散と角度散乱が増加したこと によるものと思われる。

\section{5. 結 語}

レーストラックマイクロトロンMM50による電子線 は，エネルギー分布の拡がりが小さく，フォトンバッ クグラウンドは低く，PDD曲線の線量下降部の公配は 急峻で治療領域は深部にまで行き渡っている。これら の要因として，スキャンビーム方式の採用により MM50の照射へッドには平坦化フィルタ及び散乱箔が ない $(15 \mathrm{MeV}$ 以上では非常に薄い散乱箔を使用)こと， またへッド内での散乱線を軽減するため照射へッド内 がへリウムガスで充たされていることが考えられる。 MM50の電子線はPDD曲線において急勾配に減少して
ゼロ付近に達し，その線量分布は標的体積に集中する ため有用であると思われる。この臨床的に有意な線質 特性を生かした，標的体積への線量の集中性を向上さ せる照射技術の開発が今後の課題である。最も実用化 に近いところでは，照射へッド内のマルチリーフコリ メータ (MLC)のみで照射が可能な $20 \mathrm{MeV}$ 以上の電子 線とX線の併用による，強度変調を加えた照射方法5) がある。また将来的な構想として，電子線を主体とし たスキャンビームの位置制御およびMLCのダイナミ ックな動きの連動によるIMRT等がある。今後, MM50電子線の線質特性を生かした照射技術の開発を 早急に手掛けなけれげならない。

\section{謝 辞}

稿を終えるにあたり，本稿についてご指導をいただ いた当院放射線治療部徳植公一医長，当センター放射 線治療部技師の皆様，レーストラックマイクロトロン のシステムに関する技術的なご助言をいただいた株式 会社日立メディコの杉山勝也氏，三次元走查式水ファ ントムによるスキャンビーム方式の測定についてご助 言をいただいた東洋メディック株式会社の荒木教行氏 に深く感謝いたします。

本論文の要旨は第41回秋季学術大会 (2000年10月, 千葉)において発表した。

\section{参考文献}

1) Brahme A and Svensson $\mathrm{H}$ : Radiation beam characteristics of a $22 \mathrm{MeV}$ microtron. Acta Radiol Oncol, 18, 244-272,(1979).

2) Green MA, Rowe EM, Trzeciak WS, et al.: Design and operation of the $100 \mathrm{MeV}$ Aladdin microtron injector. IEEE Transactions on Nuclear Science, 28, 2074-2076,(1981).

3) Greening JR：森内和之，高田信久訳：放射線量計測の基 礎. 地人書館，東京，(1990）.

4) ICRU Report 35, Radiation dosimetry: Electron beams with energies between 1 and $50 \mathrm{MeV}$. International Commission on Radiation Units and Measurements, Bethesda, MD, (1984).

5) Karlsson $M$ and Zackrisson B: Exploration of new treatment modalities offered by high energy (up to $50 \mathrm{MeV}$ ) electrons and photons. Radiother Oncol, 43, 303-309, (1997).

6) Karlsson M, Nystrom H, and Svensson H: Electron beam characteristics of the MM50 racetrack microtron. Med Phys, $19,307-315,(1991)$
7) Khan FM, Doppke KP, Hogstrom KR, et al.: Clinical electron beam dosimetry. Report of AAPM Radiation Therapy Committee Task Group No. 25. Med Phys, 18, 73-109, (1991).

8) Masterson ME, Chui CS, Febo R, et al.: Beam characteristics of a new generation $50-\mathrm{MeV}$ racetrack microtron. Med Phys, 22, 781-792,(1995).

9) Scharf W：稲田哲雄監：遠藤有聲訳：医生物学用加速器総 論. 医療科学社, 東京, (1998).

10)保科正夫，小川仁司，笹森浩司，他：放射線治療ビームに 抢ける電離箱線量計のヒステリシス現象. 日放技学誌, 56 (11)，1348-1355，(2000).

11）日本医学放射線学会物理部会編：放射線治療における高工 ネルギーX線及び電子線の吸収線量の標準測定法. 通商産 業研究社, 東京, (1989). 
Fig. 1 MM50システムの概略図.

電子線は偏向主電磁石の磁力を受けて回転し，リニアックに再入射して加速される。また，ビーム取り出し用電磁石によ って外部に電子線を取り出す，その後，電子線はスイッチングマグネット，四極子電磁石，ベンディングマグネットから なるビームトランスポートシステムによって輸送される。

Fig. 2 X線および電子線のスキャンパターンについての説明図.

X線のスキャンパターンは円軌道, 一方電子線はラスタ状にスキャンしてビーム強度を均一にしている。

Fig. 3 電子線の深部量百分率(PDD) 曲線と各パラメータ.

$D_{x}$ : フォトンバックグラウンド. $R_{p}$ : 実用飛程. $R_{q}$ : 最大飛程. $R_{90}$ : 最大線量の $90 \%$ レ゙ルの深さ (治療飛程). $G_{0}:$ 線量 下降部の公配.

Fig. 4 MM50およびMM22の電子線のPDD曲線.

MM22すべてのエネルギーおよびMM50の10～15MeVは可変アプリケータを装着し，MM50の20〜50MeVについてはアプ リケータを装着せず照射ヘッド内のマルチリーフコリメータ(MLC)により測定した(通常の使用状態)。平均入射エネルギ ー10MeV以下はNACP02チェンバ，10MeVを超える場合はRKチェンバを使用し，水ファントムで測定した.

Fig. 5 MM50とMM22の電子線について, 公称エネルギーと表面における最頻エネルギーの差.

MM50 12MeVの電子線は15MeVの電子線をグラファイトで減速して取り出している. MLC(マルチリーフコリメータ).

Fig. 6 MM50とMM22の電子線について, PDDによるフォトンバックグラウンドの比較.

MM50 12MeVの電子線は15MeVの電子線をグラファイトで減速して取り出している. MLC(マルチリーフコリメータ).

Fig. 7 MM50とMM22の電子線について, PDDによる表面線量の比較.

水等価固体ファントムとMarkusチェンバを使用して表面線量を測定した，MM50 12MeVの電子線は $15 \mathrm{MeV}$ 電子線をグ ラファイトで減速して取り出している. MLC(マルチリーフコリメータ).

Fig. 8 MM50とMM22の電子線について $R_{90}$ の比較.

MM50 12MeVの電子線は15MeVの電子線をグラファイトで減速して取り出している. MLC(マルチリーフコリメータ).

Fig. 9 MM50とMM22の電子線について $G_{0}$ の比較.

MM50 12MeVの電子線は15MeVの電子線をグラファイトで減速して取り出している，MLC(マルチリーフコリメータ).

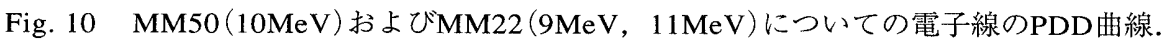

MM50, MM22ともに可変アプリケータを装着して測定した.

Fig. 11 同一エネルギー (20MeV)におけるMM50とMM22の電子線のPDD曲線.

MM22は可変アプリケータを装着し，MM50はアプリケータを装着せず照射ヘッド内のマルチリーフコリメータ(MLC)に より測定した.

Table

RFA300PlusによるMM50電子線のPDD曲線の測定条件. 